\title{
Salmer i kirke og skole
}

Av MARIt Rong

In the light of the Lutheran hymn tradition, the article investigates how the Plan for Christian Education of the Church of Norway reflects on hymn singing. The author compares hymn lists from a few congregations to the hymns in school songbooks. The article discuss the purpose and intention of hymn singing, and the correspondence between hymns used in church and the RLE subject. The core question is whether hymn singing is an expression of faith or of culture, and how hymn singing influences on identity.

Keywords: Hymn singing in church • Christian education • Identification • Hymns in school songbooks - The curriculum of the RLE subject

Marit Rong, PhD, førsteamanuensis i RLE v/Høgskolen i Bergen, Postboks 7030, 5020 Bergen, E-post:Marit.Rong@hib.no

«Ta sangen tilbake i skulen» lyder overskriften på Alf Kjetil Walgermos kommentar i Vårt Land 24. april 2015. Han slår fast: «Nordmenn er eit syngande folk. Songen sit djupt i oss ...» (Walgermo, 2015). Program som «Salmeboka minutt for minutt», «Sangtimen $\gg$ og sangarrangementer av ulike slag har det siste året fått stor medieoppmerksomhet, noe som viser en fornyet interesse for den norske fellessangen. Sangen i skolen, derimot, er på vikende front. Den naturlige plass som den har hatt i norsk skole, er redusert parallelt med innføring av nye læreplaner og på grunn av lærere som ikke synger med elevene sine, noe flere av artiklene i antologien Med sang! Perspektiver på norske skolesangbøker etter 1814 dokumenterer (Bjørnstad, Olsen \& Rong, 2014). Dette er en utvikling som er verdt å diskutere fordi sangen i skolen har vært et viktig grunnlag for utvikling av folkets fellessang. Barn har tilegnet seg musikalsk og kulturelt tradisjonsstoff som kommer dem til nytte gjennom hele livet.
Mitt spørsmål er: Når sangens posisjon i skolen har mistet noe av sitt fotfeste, hvordan står det da til med sangen i kirken? Salmesang har vært og er en grunnleggende uttrykksform både som trosuttrykk og som pedagogisk virkemiddel. Korvirksomhet for barn og voksne har stått sterkt i menighetsarbeid. Sangen tilfører individet og fellesskapet kunnskap, dannelse, gir musikalske opplevelser og er sosialt byggende. Jeg vil i denne artikkelen undersøke hvordan Den norske kirkes (Dnk) trosopplæringsplan vektlegger salmesang, hva som kjennetegner utvalget av salmer, og sammenholde dette med salmers plass og funksjon i skolen. Dette vil jeg gjøre ved å undersøke hvordan trosopplæringsplanen omtaler salmesangens funksjon i kirken, og drøfte hvordan dette forholder seg til luthersk salmetradisjon. Som materiale vil jeg bruke noen få salmeplaner fra ulike menigheter. Jeg vil sammenligne salmeutvalget $i$ kirken med salmeutvalget i utvalgte skolesangbøker og drøfte salmesangens plass i hen- 
holdsvis kirke og skole i dag.

I Norge finnes det relativt lite forskning på tema knyttet til fellessang, det være seg både empirisk og hermeneutisk forskning. Det gjelder både for sangsamlinger og sangers innholdsmessige funksjon og budskap. Det samme er tilfelle for salmer og salmesang generelt, også salmer ment for barn. Med sang! undersøker skolesangbøker som sangsamlinger.Det vil si at forfattere fra et bredt faglig spekter med ulik yrkesbakgrunn analyserer og drøfter idegrunnlag, profil og utvikling $i$ et stort utvalg av norske skolesangbøker. ${ }^{1}$ Antologien er en kvalitativ undersøkelse av tekster, ikke av hvordan sang faktisk anvendes i dagens skole.

Den eneste kvantitative salmeundersøkelsen i Norden er så vidt jeg vet det omfattende hymnologiske forskningsprosjektet Dejlig er jorden. Psalmens roll $i$ nutida nordiskt kultur-och samhällsliv, også omtalt som Nordhymn-undersøkelsen, som ble publisert i 2001 (Hansson, Bohlin \& Straarup, 2001). Ettersom datamaterialet fra denne undersøkelsen ble innsamlet for 20 år siden (1995), er det vanskelig uten videre å overføre funnene til dagens samfunn. Prosjektet gir likevel verdifull bakgrunn for denne artikkelen. Nordhymn-undersøkelsen ble videreført i et mer spesifikt prosjekt om Martin Luthers psalmer i de nordiska folkens liv, publisert i 2008 (Selander \& Hansson, 2008b). Her er salmeutvalget begrenset til Luthers salmer.

I Med sang! skrev jeg og Stig Wernø Holter en artikkel om salmenes plass i skolesangbøkene (Rong \& Holter, 2014). Fordi det ikke finnes noen kvantitative undersøkelser av hva som faktisk synges i skolen, verken allmenne eller religiøse sanger, har vi benyttet et utvalg skolesangbøker for å undersøke salmens posisjon i skolen. ${ }^{2}$ Både skolen - representert ved skolesangbøker og læreplaner - og kirken representert gjennom sin generelle trosopplæringsplan og lokale salmeplaner - har barn som målgruppe. Kirkens målgruppe er barn og unge i alderen 0 til 18 år, mens skolesangbøkene har barn i grunnskolen som sin målgruppe, dvs. barn i alderen 6 til 15 år. Kirkens plan omfatter altså et større aldersspenn.

I motsetning til skolesangbøkene, som tilbyr et stort utvalg sanger som lærere kan velge fra, er trosopplæringens salmeplaner noe vi med større sannsynlighet kan si er i bruk lokalt, dels fordi de er av nyere dato enn salmeutvalget i skolesangbøkene, og dels fordi de som oftest knyttes opp mot spesifikke trosopplæringstiltak og/eller aldersgrupper.

\section{SALMENES PLASS I TROSOPP- LÆRINGSPLANEN}

\section{Sangens og musikkens plass i kirkens trosopplæringsplan}

Dnk's trosopplæringsplan Gud gir - vi deler av 2010 tar for gitt at bruk av salmer hører hjemme i opplæringen, men den utdyper ikke salmens eller salmesangens plass og funksjon, verken prinsipielt eller ved å nevne kriterier for valg av salmer. Den gir heller ikke eksempler på konkrete salmer.

Forordet opplyser at trosopplæringsplanen er et ledd $i$ en kontinuerlig utvikling av Dnk som evangelisk-luthersk folkekirke. Den er sammen med kirkens øvrige retningsgivende strategier og planer et middel for å sti-

\footnotetext{
1 Pedagoger, musikere, musikologer, komponister, litteraturvitere, teologer og bibliotekarer.

2 Det finnes en del lokalt avgrensede undersøkelser. Jeg vil peke på to slike: Hege Bjørnestøl Bechmann og Ingunn Folkestad Breisteins forskningsundersøkelse «Tør du synge den sangen fortsatt?» som drøfter hvordan sang og musikk brukes i KRLfaget i seks skoler i Agder (Beckmann \& Breistein, 2007), og Jan Røshols undersøkelse av 2007: «Bruk av salmer i KRL-faget. Undersøkelse ved 3 skoler i en bydel i Bergen» (Røshol, 2007). Jeg har ikke anvendt slike undersøkelser i min drøfting fordi de er for lokalt basert for mitt formål.
} 
mulere til menighetsutvikling (Dnk, 2010, s. 3). Målet er at alle døpte barn kan få hjelp til å leve i troen på Jesus i menighetens fellesskap «der alle har noe å lære når vi sammen utforsker troens kilder og uttrykksformer» (s. 52, omslagets baksidetekst). Planen ønsker «å holde sammen den enkeltes livssituasjon, kirkens tro og tradisjon og et fokus på kristen tro i praksis» (s. 52). Dette skal bidra til at «[b]arn og unge skal få anledning til å uttrykke seg selv, tro, tvil, tilbedelse, glede og klage gjennom salmer, lovsang, musikk og andre kulturuttrykk» (s. 16). Videre er «trosopplæring» en danningsprosess der oppdragelse, undervisning, tradisjonsformidling og kristen tro i praksis spiller sammen» (s. 5). I motsetning til skolens kulturelle og undervisende sikte har Dnk's trosopplæring i tillegg et forkynnende sikte. Dette har naturlig nok konsekvenser for salmevalget $i$ henholdsvis skole og kirke.

I trosopplæringsplanen er salmesang hovedsakelig omtalt i kapitlet «Musikk og kultur». Kapitlet slår fast at «[m]enighetens musikalske og kulturelle virksomhet er trosopplæring i bred forstand, og utgjør viktig innhold, arenaer og arbeidsmåter i trosopplæringen» (s. 32). Musikalsk og kulturell virksomhet har en tredobbel funksjon; «barn og unge kan være både mottakere, deltakere og medarbeidere i menighetens lærende fellesskap». «Gjennom arbeid med $[\ldots]$ liturgi og salmer både lares og erfares troen, og den deles med andre» (s. 32, mine uthevinger). Planen har to generelle rettledninger for sangutvalg. For det første skal « $\ll \mathrm{u}]$ tvalget av salmer, san- ger og andre uttrykksformer i trosopplæringen $[\ldots]$ gjenspeile mangfold og ivareta både tradisjonsformidling og fornyelse» (s. 32, mine uthevinger). For det andre skal $\ll[\mathrm{b}]$ arn og unge $[\ldots]$ lære sentrale salmer knyttet til høytidene» (s. 16). At høytidssalmer fremheves som de viktigste, stemmer godt overens med skolesangbøkenes salmer og læreplanens vekt på kunnskap om religiøse høytider (Pedlex. Norsk skoleinformasjon, 2013). ${ }^{3}$

Ut over dette er salmesang og bruk av salmer lite kommentert eller begrunnet i trosopplæringsplanen. I kapitlet om arbeid med barn i aldersgruppen 6-12 år konstateres det kort at salmer er egnet som motivasjon for utenatlæring (s. 21f). I kapitlet om den gudstjenestelige dimensjonen er salmer omtalt som én av mange uttrykksformer, og sang noe barn og unge kan delta i som aktører (s. 30). Salmer er også en god arena for læring (s. 34), og bruk av salmer kan gi gode muligheter for tverrfaglig samarbeid mellom menighetens ansatte (s. 32). I tre av planens seks eksempelfortellinger er salmer og sang referert til som en selvsagt aktivitet i kristne møtefora (s. 10, $11 \mathrm{og} 12$ ). Salmesang forutsettes altså som naturlig hjemmehørende i kirkelige aktiviteter rettet mot barn og unge.

Tross dette finner jeg i Gud gir - vi deler ingen reflektert eller samlende tanke om salmers betydning og plass. Planen forutsetter imidlertid at hver menighet skal utvikle sin egen lokale trosopplæringsplan der de skal velge sitt lokale salmerepertoar. Altså tar planen for gitt at salmesang skjer i alle landets menigheter. Det gir likevel grunn til undring

\footnotetext{
3 I motsetning til Lereplanverket for den 10-årige grunnskolen av 1997 (L97) har Kunnskapsløftet av 2006 (LK06) ingen liste over stamsalmer/kjernesalmer. L97 var en svært detaljert utformet læreplan for alle fag. LK06 er derimot en kortfattet rammeplan basert på måloppnåelse og utvikling av grunnleggende ferdigheter. Kjennskap til salmer nevnes helt kort som et kompetansemål under «Kristendom»: Elevene skal «kjenne til kristen salmetradisjon og et utvalg sanger, også samiske» (Pedlex. Norsk skoleinformasjon, 2013, s. 47). Estetiske ferdigheter som sang og musikk nevnes ikke blant grunnferdighetene. Mer om dette kan leses i Eiliv Olsens artikkel «Hva er egentlig grunnleggende ferdigheter i musikkfaget?» der han argumenterer for at «musikkfaget bør fokusere på estetiske erfaringer som en grunnleggende ferdighet i seg selv» (Olsen, 2009, s. 240).
} 
at ikke grunnleggende motiver for bruk av salmesang løftes frem og drøftes i det overbyggende plandokumentet. Dette kunne gi menighetene en håndsrekning med hensyn til å legge kvalitative mål på det lokale salmeutvalget.

\section{Sangens og musikkens betydning i den evangelisk-lutherske kirke}

Martin Luther verdsatte musikk og sang svært høyt. «Jeg skulle gjerne se alle kunstarter, og ganske særlig musikken, i tjeneste for Ham som har gitt oss dem og skapt dem», sier han i sin fortale til Wittenberg-sangboken fra 1524 (Hjelde, Lønning \& Rasmussen, 1982, s. 42). Musikken omtales som en dronning over de menneskelige følelser. Videre hevder Luther at «musikken like fra verdens begynnelse av har vært iboende eller innebygget $\mathrm{i}$ alle skapninger $\gg$ (Hjelde et al., 1982, s. 44), og han vil gjerne at ungdommen «må oppdras i musikk og andre skikkelige kunstarter» (Hjelde et al., 1982, s. 44).

Luthers intensjon var at salmer og salmesang skulle bli en del av de kristnes liv, en hjelp til å tilegne seg troen og bevare den (Selander \& Hansson, 2008a, s. 13f). Den lutherske salmesangen ble et gjennombrudd for den folkespråklige menighetssangen i gudstjenesten. Som Bernice Sundkvist sier: «Den lutherska församlingssången blev ett uttryck för ett praktiskt utövande av det allmänna prästadömet» (Sundkvist, 2008, s. 26).

Lutherske kirker har alltid holdt salmesang høyt i hevd. Forkynnelse og svar på forkynnelsen blir i salmen vevd sammen til en uatskillelig helhet. «Kirken synger som den tror og tror som den synger» (Holter, 2008, s. 243f). I salmen forenes tekst med musikk, teologisk lære med menneskers livserfaring, kunnskap med menneskelige følelser. Hans Thomissøn peker i sin fortale til Den danske psalmebog av 1569 på samspillet mellom tekst og musikk. Melodien gir teksten liv, og slik blir den internalisert:

Guds ord er i seg selv den allerlifligste Musica, som gir trøst og liv midt $i$ dødsens nød og rettelig kan fryde hjertet. Men når det kommer en søt og liflig sang og melodi dertil [...], da får denne sang en ny kraft og går dypere inn $i$ hjertet, så at teksten, som er så godt som sangens sjel, rører hjertet mer og glemmes ikke lettelig. (Modernisert ortografi)

$$
\text { (Thomissøn, 1569, s. forord) }
$$

Språk er mer enn tekst og tale. Salmen har mange språklige uttrykk som dekker en multifunksjon. Å huske en salme kan styrkes gjennom melodier og tekster som vekker følelser. Dypest sett intenderer en salme å forkynne til tro, noe som er problematisk i skolesammenheng. I Nordhymn-undersøkelsen defineres en salmes funksjon som «den effekt psalmerna har på människor när de kommer i kontakt med psalmerna» (Hansson et al., 2001, s. 11). Hva dette innebærer for det enkelte menneske er individuelt, enhver kan tolke innholdet og oppleve en og samme salme på hver sin måte. Salmer sies ofte å ha en identitetsskapende effekt både på grunn av kulturell fellesarv og individuelle erfaringer og følelser knyttet til bestemte salmer. Kombinasjonen av verbalt språk og musikk, lytting og egen sang, er en form for språkmangfold som kan fungere inkluderende.

Salmen er en felles kirkelig uttrykksform for tro og erfaringer. Som salmebokkomiteen av 1981 uttrykker det: «Ved salmen kan Guds ord legges menigheten i munnen på en slik måte at det både blir lære og undervisning, bekjennelse og lovprisning av det» (NOU, 1981, s. 8). Det stilles flere krav til en kvalitetsmessig god salme. Innen hymnologien defineres disse oftest som det dog- 
matiske kravet som skal sikre at salmen er i samsvar med Bibel og bekjennelse, det poetiske/kunstneriske kravet som stiller litterære kvalitetskrav, kravet til «det «hjertelige» som skal være et korrektiv til det dogmatiske kravet, kravet til folkelighet som er et korrektiv til det poetiske/kunstneriske kravet og sikrer salmeboken som en bruksbok for menigheten, det liturgiske kravet som støtter opp om gudstjenestens funksjoner, og det musikalske kravet som ser salmen som en enhet mellom melodi og tekst. I de senere år har også krav om inkluderende språk og kontekstualitet kommet til (Holter, 2008, s. 243-246). Bortsett fra det liturgiske kravet er dette krav som kan stilles til salmer både i kirken og i skolen. Konteksten for salmens bruk vil være avgjørende for egnethet.

En sunget tekst starter en resepsjonsprosess hos alle sangere. En salme som skal fungere optimalt, må synges. En salmetekst eller melodilinje som leses, står langt svakere med tanke på innlæring og internalisering. Det finnes flere eksempler på at samspillet mellom tekst og melodi er avgjørende for en salmes gjennomslagskraft. Svein Ellingsens dåpssalme «Fylt av glede over livets under» kom inn i Salmer 1973 til en melodi av Knut Nystedt. Den ble lite brukt og var dermed lite kjent. Da teksten ble tatt med i Norsk Salmerbok (NoS) i 1985 til en ny melodi av Egil Hovland, ble den en av de nyere salmene som raskt vant fotfeste og popularitet. Grunnen til dette lar seg ikke uten videre forklare. Både Nystedt og Hovland var dyktige komponister. Årsaken kan ha med selve melodienes vanskelighetsgrad å gjøre, det kan bero på at den nye melodien ble «markedsført» i fora som hadde stor gjennomslagskraft, f.eks. gjennom media, eller at den nye melodien appellerer mer til følelser, glede og undring, dvs. at tekst og melodi «kler hverandre», jf. Thomissøn: «[T]eksten $[\ldots]$ rører hjertet mer og glemmes ikke lettelig» (Thomissøn, 1569 , s. forord).

\section{SALMEUTVALGET I LOKALE \\ TROSOPPLÆRINGSPLANER}

«For en stor del har f o $1 \mathrm{k} \mathrm{e} \mathrm{t} \mathrm{-} \mathrm{i} \mathrm{dette} \mathrm{til-}$ felle den syngende menighet - på forhånd utvalgt de sanger som gir uttrykk for hva en tror, opplever og føler», uttalte salmebokkomiteen i 1981 (NOU, 1981, s. 8). For å se hva menighetene har valgt å la barn og unge synge i forbindelse med trosopplæringen, har jeg plukket ut lokale salmeplaner fra åtte tilfeldig valgte menigheter som har fått godkjent sine planer. Disse har jeg hentet fra trosopplæringens ressursbank. ${ }^{4}$ Menighetene representerer alle landsdeler, det er menigheter i større bysamfunn og små landsmenigheter, og det er menigheter som anvender både bokmål og nynorsk. Den enkelte menighet er anonymisert, og salmeutvalget blir behandlet som en samlet enhet. Mitt materiale er altfor lite til å kunne si noe om salmeutvalg i kirken generelt. Men det kan gi en liten pekepinn om hvilke salmer og salmetyper som synges $i$ barne- og ungdomsarbeidet i Dnk's menigheter, og det kan brukes for å se etter sammenhenger mellom kirkens og skolesangbøkenes salmeutvalg.

Utvalget av salmer i de ulike lokale salmeplanene varierer fra 21 til 95 salmer. For de åtte menighetene gir dette et snitt på 53 salmer. Totalt har jeg registrert 219 forskjellige salmer som forekommer 412 ganger. Jeg har prøvd å finne hvor menighetene kan ha hentet de enkelte salmene fra. Til dette har jeg valgt de mest brukte salmebøkene for barn

4 Den norske kirke, «Ressursbanken. Planarbeid» http://www.ressursbanken.no/planarbeid/ Nedlastet september 2014. 
samt kirkens offisielle salmebøker. Antall salmer viser hvor mange av salmene i trosopplæringslistene som finnes i den enkelte bok.

- Sanger for de små, 28 salmer, (Rypdal, 1973)

- Barnesalmeboka, 130 salmer, (Verbum \& IKO-Forlaget AS, 1999)

- Norsk Salmebok, 92 salmer, (Dnk, 1985)

- Salmer 1997, 38 salmer, (Dnk, 1997)

- Norsk Salmebok 2013 (N 13), 138 salmer, (Dnk, 2013)

43 av de 219 salmene finnes ikke i noen av disse salmebøkene. ${ }^{5}$ For oversiktens skyld har jeg utelatt disse fra mitt tallmateriale, og jeg forholder meg da til 176 ulike salmer.

55 av salmene er i NoS markert i kursiv i innholdsregisteret. Dette innebærer at de er kjernesalmer som anses som spesielt egnet til familiegudstjenester og samlinger med barn. $N 13$ har et (godt skjult) register på om lag 80 salmer som pekes på som egnet til trosopplæring (N 13, 2013, s. 1412-1415). Kjernesalmer betegnes også som stamsalmer. Tidligere læreplaner i fagene kristendomskunnskap og musikk inneholdt registre over stamsalmer. Stamsalmene var ment som minimumskrav til hvilke sanger elevene burde lære. ${ }^{6}$

Kirkens kjernesalmer er ikke utelukkende barnesalmer, de retter seg også mot voksne. Salmebokkommisjonen av 1981 pekte på at overgangen mellom barnesalme og voksensalme er flytende. «Den gode barnesalmen talar og til den vaksne og er i alt sitt einfelde naturleg å syngje for heile kyrkjelyden» (NOU, 1981, s. 24). Denne tankegangen støtter opp under trosopplæringsplanens syn på gudstjenesten som menighetens hovedsamling og felles møtepunkt for barn, unge og voksne. I gudstjenesterevisjonen av 2011 ble «Ordning for familiegudstjeneste» fjernet til fordel for én felles hovedgudstjeneste (Dnk, 2011).

\section{Salmenes 《10 på topp»}

Hvilke salmer er de mest populære i henholdsvis kirkens trosopplæringsplaner, skolesangbøkene og Nordhymn-undersøkelsen? I menighetens lokale salmeplanene er ti salmer representert $\mathrm{i}$ henholdsvis åtte, sju og seks av de åtte menighetene. Jeg har delt salmene inn $i$ kategorier som er tilnærmet lik de kategoriene jeg brukte for å registrere salmer i skolesangbøkene. Dersom en salme har like mange forekomster, er de rangert alfabetisk (se tabell neste side).

Listen inneholder to julesalmer, to påskesalmer, tre bønnesalmer, en «kirkesalme», en med skapelsen som motiv og en kveldssalme. De neste ti salmene i rekken er: «Kom, syng for vår Gud», «Deg å få skode», «Deilig er jorden», «Det lyser i stille grender», «Det skjer et under i verden», «Fylt av glede», «Herre Gud, ditt dyre navn og ære», «No livnar det i lundar», «Påskemorgen slukker sorgen $\gg$ og «Vi syng med takk og glede».

Samlet sett representerer trosopplæringens salmeliste så vel norske som oversatte utenlandske salmer. At salmene hentes fra ulike land, viser et internasjonalt felles sangrepertoar. Videre inneholder salmelisten $i$ hovedsak eldre salmer, den eldste er skrevet i 1820, den yngste i 1988. Forfatterne er hovedsakelig menn, men også kvinner er representert. Salmeutvalget har overvekt på høytidssalmer og barnesalmer brukt som kveldssalmer (kategorien bønn).

\footnotetext{
5 Flere av tekstene er imidlertid godt kjent fra f.eks. kristne organisasjoners sangbøker, mens andre kan være ukjente lokale salmer.

Noen av disse sangene finnes også i skolesangbøkenes repertoar.

6 Slike registre er omtalt mer inngående i flere av artiklene i Bjørnstad, Olsen, Rong: Med sang!
} 


\begin{tabular}{|l|l|l|l|l|l|}
\hline Nr. & Salmetittel & $\begin{array}{l}\text { Mål- } \\
\text { form }\end{array}$ & Kategori & Forfatter & $\begin{array}{l}\text { Sum } \\
\text { fore- } \\
\text { komster }\end{array}$ \\
\hline 1 & Et barn er født i Betlehem & B + N & Jul & N.S.F. Grundtvig 1820 & 8 \\
\hline 2 & Deg være ære & B & Påske & Edmond L. Budry 1885 & 7 \\
\hline 3 & Dine hender er fulle av blomster & B + N & Påske & Marcello Giombini 1970 & 7 \\
\hline 4 & Jeg folder mine hender små & B + N & Bønn & Torbjørn Egner 1948 & 7 \\
\hline 5 & Måne og sol & B + N & Kirke & Britt G. Hallqvist 1973 & 7 \\
\hline 6 & Tenn lys! & B + N & Jul & Eyvind Skeie 1988 & 7 \\
\hline 7 & Hvem har skapt alle blomstene & B + N & $\begin{array}{l}\text { Skap- } \\
\text { else }\end{array}$ & $\begin{array}{l}\text { Ukjent/svensk skillingstrykk } \\
\text { tidlig 1900-tall }\end{array}$ & 6 \\
\hline 8 & Jeg er trygg hos deg & B + N & Bønn & Leif Lundberg 1973 & 6 \\
\hline 9 & Kjære Gud, jeg har det godt & B + N & Døgn & Margrethe Munthe 1907 & 6 \\
\hline 10 & Vær meg nær, å Gud & B & Bønn & $\begin{array}{l}\text { Afro-amerikansk spiritual } \\
\text { oversatt 1972 av Elsa Joranger }\end{array}$ & 6 \\
\hline
\end{tabular}

Salmefavorittene i de åtte skolesangbøkene jeg undersøkte er: ${ }^{7}$

1 1. «Deilig er jorden»

2 2. «Gud sign vår konge god»

3 3. «Ja, vi elsker»

4 4. «No livnar det i lundar»

5 5. «Det kimer nå til julefest»

6 6. «Fager kveldsol smiler»

7 7. «Alltid freidig»

8 8. «Deilig er den himmel blå»

9 9. «Det lyser i stille grender»

10 10. «Glade jul»

11 11. «Gud signe Noregs land»

12 12. «Gud signe vårt dyre fedreland»

13 13. «Jeg er så glad hver julekveld»

I denne listen er fire av dem nasjonalsalmer, seks er julesalmer, en salme er knyttet til pinse/året, en er knyttet til døgnet/kveldsbønn og en til kristent liv. ${ }^{8}$
Den norske «10 på topp» -listen fra Nordhymn-undersøkelsen er:

141 . «Deilig er jorden»

15 2. «Kjærlighet fra Gud»

163. «Alltid freidig»

17 4. «O bli hos meg»

18 5. «Deg være ære»

$196 . \ll$ Lei, milde ljos»

207. «Påskemorgen slukker sorgen»

$218 . \ll \AA ̊$ leva, det er å elska»

$229 . \ll$ «red dina vida vingar»

23 10. «Fagert er landet»

(Tveit, 2001, s. 260-271)

Det er relativt stort avvik mellom favorittsalmene i trosopplæringens salmeplaner, Nordhymn-undersøkelsen og skolesangbøkene. De tre listene har bare én favorittsalme felles: «Deg være ære». Nordhymnlisten og skolesangboklisten har to felles salmer:

\footnotetext{
7 Lars Søraas: Sangboka, 1939- og 1958-utgaven, Mads Berg: Skolens sangbok, 1940- og 1970-utgaven, G. Hulaas, R. Nordal, H. Stordal: Folkeskolens sangbok I og II, utgitt 1960 og 1961, F. Benestad, T. Hauso, A. Klakegg, F. Lunde: Syng med. Sangbok for 3.-6.klasse, 1994, T. Gravlie: Sangbok for skolen, 1997, A. Amsrud og T. Bjørnstad: Sang i Norge, 2008.

8 Denne listen inneholder 13 salmer fordi den viser salmer som forekommer i henholdsvis åtte, sju og seks skolesangbøker. De salmene som hadde seks forekomster, kan ikke rangeres innen gruppen.
} 
$\ll$ Deilig er jorden $»$ og «Alltid freidig». Om vi utvider trosopplæringens liste med de som har fem forekomster, finner vi ytterligere tre felles salmer fra hver av listene: «Deilig er jorden $\gg$, «Påskemorgen» og «Det lyser i stille grender $\gg$.

Det er flere sammenfallende trekk for alle tre listene. Salmer på topp er i hovedsak tradisjonsstoff av eldre dato. De har vært i bruk i flere generasjoner. Dette viser at salmer trenger lang tid for å komme i favorittposisjon, dels fordi det i seg selv tar tid for en salme å få innpass i henholdsvis salmebøker og skolesangbøker, dels fordi sangarven traderes gjennom generasjoner, og foreldre synger for sine barn de sangene de selv har lært og fått et forhold til. De åtte skolesangbøkene jeg undersøkte, ble utgitt fra 1939 til 2008, fem av dem er fra før 1970. Salmelistene viser likevel at salmerepertoaret fornyer seg i takt med skiftende tider. Trosopplæringens liste har flest salmer av «nyere» dato fordi materialet undersøkelsen bygger på er av ny dato.

Salmene «Jeg ertrygghos deg» og «Hvem har skapt alle blomstene», «Tenn lys $\gg$, samt «Kom, syng for vår Gud» finnes ikke i de skolesangbøkene jeg undersøkte. I salmebøkene, derimot, er de representert. Dette kan ha flere årsaker. De to første er typiske barnesalmer rettet mot de minste barna, altså barn i barnehagealder som er utenfor skolens målgruppe. De to siste salmene er nyere sanger. «Tenn lys» er en sang med tekst av Eyvind Skeie og melodi av Sigvald Tveit, opprinnelig brukt i TV-programmet Portveien, adventsprogrammet til NRK fra 1987. Den ble svært populær, og fra TV kom den inn i $S 97$ ti år senere. «Kom, syng for vår Gud» er en brasiliansk folkevise som ble oversatt til norsk i 1995 av Sindre Eide. Den er også oppført i salmebøkene med sin opprinnelige brasilianske tekst «Cantai ao Senhor». Slik står den som representant for den økumeniske fellessangen der salmer fra andre land og kirker inkluderes i det norske salmetilfanget. Hvilke salmer Nordhymn-undersøkelsen inneholder ut over $\ll 10$ på topp $»-$ listen, gir ikke Nordhymn-undersøkelsen noen opplysninger om.

\section{Luthersalmene}

Luthers egne salmer er fraværende i menighetenes salmeplaner, selv ikke «Vår Gud han er så fast en borg» er tatt med. To menigheter har imidlertid i sitt salmeutvalg tatt med Luthers oversettelse av den latinske hymnen «Veni creator spiritus», «Kom, Hellig Ånd med skapermakt», med en forenklet melodi tilpasset menighetssang (tekst fra 1524, melodi fra samme år basert på en melodi fra ca. 1000).

Salmebøkene inneholder, ikke uventet, et større utvalg av Luthers salmer. NoS og N 13 har med 16 av Luthers egne salmer. ${ }^{9}$ NoS markerer tre av dem som kjernesalmer. I $N$ 13 er ingen av Luthersalmene oppgitt i listen over salmer egnet for trosopplæring (Den norske kirke, 2013, s. 1412-1414). Dette kan tyde på at bare få av Luthers salmer anses som aktuelle for barn i dag. Inntrykket styrkes av at Luthers salmer heller ikke har vunnet innpass i skolesangbøkene, med unntak av «Vår Gud han er så fast en borg» og Luthers oversettelse av «Jeg synger julekvad». Luther skrev flere av sine salmer som barnesalmer, bl.a. «Fra himlen høyt jeg kommer her» og «Gud, hold oss oppe ved ditt ord» (Holter, 2011, s. 388). ${ }^{10}$

\footnotetext{
9 Jeg omtaler Luthers originale tekster og oversettelser under ett. Det er vanskelig å skille mellom dem fordi han gjerne brukte deler av eldre salmer og diktet videre på dem.

10 Disse salmene er fortsatt med i $N 13$.
} 
Konteksten salmene ble sunget og brukt i har endret seg. Hva som anses som relevant teologi for barn, skifter med generasjonene. Tross dette finner jeg grunn til å spørre hvorfor Luthers salmer har blitt så marginale. Salmebokkommisjonen for NoS berørte dette spørsmålet i sin utredning. En av deres retningslinjer var at salmeboken skal inneholde salmer som viser historisk kontinuitet, og da særlig salmer fra reformasjonstiden. Samtidig understreket kommisjonen at salmeboken ikke «skal være en slags antologi over kristen diktning ned gjennom tidene. Alt må være aktuelt relevant» fordi $\ll[\mathrm{k}]$ irken synger så sant den er en levende kirke - stadig en ny sang» (NOU 1981, s. 15).

Luthersalmenes plass i dagens kirke debatteres i Martin Luthers psalmer i de nordiska folkens liv. Eberhard Harbsmeier hevder at i skolebøkene av i dag spiller Luthers salmer kun en rolle som illustrasjon til reformasjonshistorien. I det danske konfirmasjonsmaterialet nevnes ikke Luther og hans salmer (Harbsmeier, 2008, s. 265f). Harbsmeier bruker «Vår Gud han er så fast en borg» til å underbygge sin påstand. Salmens tema er fremmed for det moderne mennesket fordi den forutsetter en kampsituasjon som ikke er vår, og den legger en patriarkalsk samfunnsforståelse til grunn. I tillegg er Luthers hovedmotiv synd og nåde $\mathrm{i}$ dag avløst av motsetningen mellom liv og død (Harbsmeier, 2008, s. 270f).

I sin oppsummering av forskningsprosjektet om Luthers salmer refererer Sven-Åke Selander til de mange krav som stilles for at en salme kan overleve: den må bli kjent, formulere en trostolkning som svarer til menneskets behov, den skal være en del av det kristne livet, den skal kunne anvendes i undervisningen av den kristne tro, den skal ha en sangbar melodi, og den skal kunne bidra i samfunnsog kulturdebatten. Han konkluderer: $\ll[\mathrm{I}]$ nte många av Luthers psalmer fyller dessa krav även i vår tid. [...] Några behöver formuleras på nytt för en ny tid. Nya psalmer behöver skrivas som svarar mot Luthers intentioner med sin psalmdiktning: «För att Guds ord också i sång kan förbliva i folket» (Selander, 2009, s. 707f).

Jeg mener at revisjoner av norske salmebøker har forsøkt å imøtekomme kravet om aktuell bildebruk og språkbruk ved å veie prinsippet om språklig revisjon mot prinsippet om tradisjon og kontinuitet (NOU, 1981, s. 15, 17), slik det er gjort med «Vår Gud han er så fast en borg». Kampmotivene står urørt, de får tale for sin tid, men «gods, ære, barn og viv» som kunne gis slipp på, er erstattet med det mer generelle utsagnet $\ll$ og røver alt vi har». Men salmen bærer likevel preg av at den er skrevet ut fra sin tid i den kontekst som formet reformasjonsteologien. En slik salme kan fungere som tradisjons- og kunnskapsformidling for lutherske kirker i dag, noe Gud gir - vi deler peker på. I aspektet «Kirkens tro og tradisjon» sies det: «Barn og unge skal få kunnskap om og kjennskap til kirken de tilhører, inkludert et kritisk perspektiv på kirkens tradisjon og historie» og peker bl.a. på $\ll[\mathrm{u}]$ tvalgte epoker og personer fra kirkehistorien som f.eks. reformasjonen, Martin Luther, ...» (Den norske kirke, 2010, s. 19). Det går likevel en grense for hvor arkaisk og fremmed et språk kan fremstå. Ikke alt gammelt kan brukes for tradisjonens skyld, heller ikke i trosopplæringens salmesang.

Dette gir grunn til å spørre i hvilken grad aktualitet har utkonkurrert Luthersalmene. «Kirkens tro og tradisjon» og «Livstolkning og livsmestring» er bærende aspekter i trosopplæringsplanen (Dnk, 2010, s. 15). Vi vet fra tidligere salmebokrevisjoner at svært mange ønsker å beholde tradisjonelle salmer og tradisjonelt salmespråk slik de har gått i 
arv fordi de gamle tekstene skaper gjenkjennelse fra egen barndom og rører ved folks religiøse røtter (Rong, 2009, s. 198f). N 13 har fanget dette ønskemålet gjennom å restaurere noen salmer tilbake til sin opprinnelige tekst, bl.a. er «Her kommer, Jesus, dine små» ført tilbake til «Her kommer dine arme små», slik den stod i Landstads reviderte salmebok av 1920 (Landstad, 1973, s. nr. 108).

Som luthersk folkekirke mener jeg det er viktig å ta vare på og anvende noen av Luthers salmer, ikke bare hans generelle lovprisning av sang og musikk. En trosopplæringsplan skal ha salmer til mange formål, også til undervisning. Om menighetene fikk noen retningslinjer for salmevalget, ville kanskje et par av Luthersalmene fortsatt synges, til tross for fremmede motiver og et til dels krevende språklig uttrykk.

\section{TEMA I TROSOPPLÆRINGENS SALMEUTVALG}

For å undersøke de innholdsmessige tema i menighetenes salmevalg, har jeg delt materialet inn i kategorier og registrert hvor mange ganger salmer hjemmehørende i kategorien forekommer ${ }^{11}$

- «Nasjonalsanger», 4 forekomster

- «Skapelse», dvs. Gud som skaper og opprettholder natur og skaperverk, 26 forekomster

- «Lovsang», inklusive takkesalmer, 27 forekomster

- «Døgnet» som har egne salmer for morgen, måltid, kveld, inklusive salmer om årstidene, 46 forekomster

- «Det kristne livet», dvs. oppdragelse, nestekjærlighet, samfunnsansvar, familien, samliv, 30 forekomster

- «Bønn» som uttrykker bekjennelse og tillit til Gud, 42 forekomster

- $\ll$ Kirke», dvs. gudstjeneste, sakramenter, kirkegang, samt salmer om døden, det kristne håp og evig liv, 60 forekomster

- Høytidene «Jul», «Påske» og «Pinse», til sammen 121 forekomster fordelt på jul: 56 forekomster, påske: 53 forekomster og pinse: 12 forekomster

- «Bibelsanger» som er bibelfortellinger gjengitt i metrisk form, 13 forekomster

Totalt antall forekomster er 369 fordelt på 176 salmer. ${ }^{12}$ Prosentvis fordeler kategoriene seg slik:

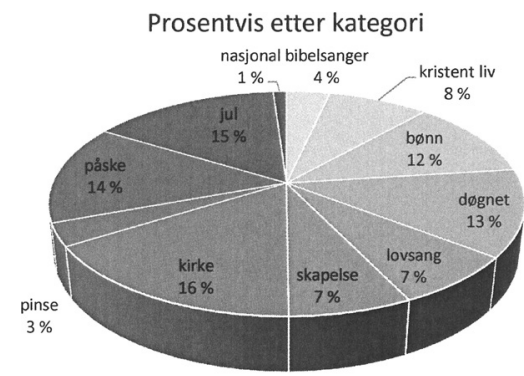

Hvilken innholdsmessig profil innehar kategoriene i trosopplæringens salmeplaner? Jeg vil kort omtale noen av de mest fremtredende motivkretsene i kirkens og skolens salmeutvalg. ${ }^{13}$

\section{Skapelsesmotivet}

I kirkens salmelister finnes skapelsesmotivet hovedsakelig i kategoriene «skapelse» og «lovsang». Disse utgjør til sammen $14 \%$

11 Å bestemme kategorier innebærer skjønn. Et håndterlig materiale krever romslige kategorier. Kategoriene er tilnærmet lik de jeg brukte da jeg registrerte salmer i skolesangbøkene. Det vil bli for omfattende i denne artikkelen å gå inn på innholdet i enkeltkategorier. Her viser jeg til min artikkel i Med sang! som omtaler motivkretser i salmene noe grundigere.

12 Sammenlikningsgrunnlaget for salmer brukt i skolen og kirken er brukbart. Skolesangbøkenes 207 ulike salmer hadde 412 forekomster i 8 skolesangbøker.

13 Hva skolen angår er disse motivkretsene mer inngående drøftet $\mathrm{i}$ «Mellom kultur og tro» (Rong \& Holter, 2014, s. 79-84). 
av salmeutvalget. Typiske salmer i kategorien «skapelse» er tradisjonssalmer som «Herre Gud, ditt dyre navn og ære» og «Syng for Herren, sol og måne». Denne kategorien inneholder også mange salmer for de minste barna, f.eks. «Fader, du har skapt meg» og «Hvem har skapt alle blomstene». Den siste er med på «10 på topp»-listen. Disse salmene er ikke med i skolesangbøkene fordi målgruppen er barn i førskolealder.

Kategorien «lovsang» omfatter salmer som priser Gud for skaperverket, inklusive skapelsen av mennesket. «Vi syng med takk og glede» og «Kom, syng for vår Gud» finnes på salmelistene til fem av de åtte menighetene sammen med «småbarnssalmen» «Takk, min Gud for hele meg».

I skolesangbøkenes salmeutvalg utgjør de samme kategoriene $15 \%$. Tradisjonssalmer som «Herre Gud, ditt dyre navn og ære» er med også her, men skolesangbøkene inneholder også sanger av mer allmennreligiøs karakter som omtaler skaperverket, f.eks. Bjørnstjerne Bjørnsons tekst «Når du vil på fiellesti $\gg$ og «I morgen er det søndag» som priser søndagen som hviledag. Ingen salmer fra denne kategorien finnes på skolesangbøkenes favorittliste. Det gjør derimot nasjonalsanger, som utgjør $5 \%$. Skapelsesmotivet er fremtredende også i disse sangene. Folkets kjærlighet til landet sammenveves med lovprisning av naturen og Gud som skaper. Dette er salmer som svært mange kan identifisere seg med, ikke minst fra et historisk og kulturelt perspektiv.

Kirkens salmeplaner har bare i liten grad med nasjonalsanger (1\%). Undringen over skapelsen, takk og lovprisning har en tydelig adressat: Gud som verdens skaper og opprettholder. Trosaspektet er altså mer fremtredende i menighetenes salmevalg enn i skolesangbøkenes salmeutvalg.

\section{Trosperspektivet og barnemotivet}

I trosopplæringens salmeplaner har salmer knyttet til kirken overtatt som ledende kategori med $16 \%$ mot skolesangbøkenes $6 \%$. I salmeplanene er fem av disse dåpssalmer og seks nattverdsalmer. Skolesangbøkene bare har én nattverdsalme: «Å, fikk jeg kun være den minste kvist» og ingen dåpssalmer. At kirkens salmeplaner har flere salmer enn skolen i denne kategorien, er ikke oppsiktsvekkende, snarere forventet. Salmeplanene avspeiler at kirken er trosopplæringens sted og at innføring i kristent liv skjer gjennom gudstjeneste, dåp og nattverd. Det kristne liv i forlengelse av dåpen er sentrum i trosopplæringen.

Salmer knyttet til høytider vever sammen trosperspektivet med det kulturelle perspektivet. Mens skolen har $23 \%$ julesalmer, har kirkens salmeplaner $15 \%$. Dette er ikke så overraskende i og med at julen er den høytiden som har sterkest feste i kulturarven, og barnemotivet er fremtredende. Julen er Jesusbarnets og barnas høytid. Jesusbarnets fødsel feires som en historisk hendelse, samtidig som inkarnasjonen bringer den transcendente evighetsdimensjonen inn i verden. Pétur Pétersson omtaler dette som at «den folkliga religionen kopplar [...] samman den uppståndne Kristus med den Jesus som är barnens bäste vän (Pétursson, 2001, s. 75). Videre sier han at de fleste synes att det är en vacker tanke att Gud låter sin son födas bland vanliga människor och att han visar sin solidaritet med de fattiga på ett så trovärdigt sätt att han låter honom födas $i$ ett stall och inte i ett slott. Det lilla Jesusbarnet, som vilar i sin trygghet $i$ krubban, blir en symbol för alla barn.

(Pétursson, 2001, s. 73)

Dette er ikke synspunkter som bare finnes i 
den allmenne folkereligiøsiteten, de er også ett aspekt i kirkens forkynnelse. I salmeplanene finnes «Et barn er født i Betlehem» hos alle de undersøkte menighetene, og kan stå som eksempel på hvordan fokus på barnet sammenbindes medtroen på Jesus som frelser.

Om salmer til påske og pinse legges til julesalmene, blir høytidssalmene både i kirkens og skolesangbøkenes salmevalg mer jevnbyrdige, for kirken $32 \%$ og i skolesangbøkene 25 $\%$. Påskesalmene er sterkt representert i trosopplæringens salmeplaner (14\%), noe de ikke var i skolesangbøkene (2\%). ${ }^{14}$ Både den eldre salmen «Deg være ære» og den nyere salmen «Dine hender er fulle av blomster» er godt representert i begge utvalgene. Det finnes imidlertid bare én pinsesalme i skolesangbøkenes utvalg: «Klokkene ringer til kirkegang» som er av mer allmenn karakter. Trosopplæringens salmeplaner har med åtte salmer. Ingen av dem finnes på $\ll 10$ på topp $»-$ listen. Den mest foretrukne er «Vinden ser vi ikke». Den er oppført på tre av menighetenes salmelister. Salmene knyttet til trosopplæringen fordeler seg på alle tre høytidene slik at utvalget avspeiler den vekt de kirkelige høytidene har. Samlet vektlegges troen på den treenige Gud.

\section{Trygghet og omsorg}

I hovedsak beskriver salmetilbudet både $\mathrm{i}$ kirke og skole en glad, livsbejaende og trygghetsskapende kristen tro uten de store friksjoner. «Vi syng med takk og glede», «Kom, syng for vår Gud» og tillitssalmer som «I dine hender, Fader blid» og «Kjære Gud, jeg har det godt» er illustrerende eksem- pler. Salmene gir uttrykk for stor tro på og tillit til Gud. Gud er den som kan ivareta de vanskelige «hvordan» og «hvorfor», de spørsmål mennesket ikke selv kan svare på. Grunnleggende livsspørsmål om tema som liv og død, ensomhet og fellesskap, angst og trygghet, tas opp på en åpen og allmennmenneskelig måte som mennesker kan kjenne seg igjen i (Rong \& Holter, 2014, s. 79-84).

Preferansen av salmer som formidler en positiv holdning til Gud og Guds omsorg, er felles både i kirkens salmeplaner og skolesangbøkenes utvalg av salmer. Dette passer til en folkekirkevirkelighet der vanskelige tema og problematisk livsinnhold kan oppleves som krevende og lite barnevennlig. ${ }^{15}$

Bruken av dur-melodier er et annet virkemiddel som forsterker inntrykket av et friksjonsfritt liv. Av de 176 salmene i kirkens salmeplaner er 148 i dur, 28 i moll. I likhet med salmeutvalget i skolesangbøkene ser det også ut som trosopplæringens salmeplaner er «prioritert melodier etter en estetikk som legger til grunn at dur representerer det glade, lyse og positive, mens moll representerer det triste, mørke og vanskelige $\gg$ (Rong \& Holter, 2014, s. 85f).

Trygghets- og omsorgsmotivet er sterkt representert i menighetenes salmeplaner f.eks. «Jeg er trygg hos deg», «Om jeg er liten eller stor», «Gud, lær meg å se» mfl. Det allmennmenneskelige og «ønskverdige» presenteres positivt i tiltro til at Gud kan gi trygghet og omsorg i alle livets forhold. Denne håpsdimensjonen er viktig i barns og voksnes liv. Likevel vil jeg spørre om den ensidige vekten på det gode og positive gir et sal-

14 De eldre skolesangbøkene forutsatte at salmeboken var i parallell bruk ved siden av skolesangboken. Begge ble gitt hver elev til odel og eie.

15 Ole Gunnar Winsnes har i artikkelen «Salmene i menneskenes hjerter» diskutert om salmer kan være bærere av tro. Han konkluderer med at de kjente salmene «Deilig er jorden» og «Ingen er så trygg i fare» setter «ord på helt sentrale momenter i en felles nordisk kristen og folkelig kulturarv» (Winsnes, 2001, s. 168). Dette er sammenfallende med tekstutvalget i min undersøkelse. Winsnes har flere interessante momenter som av plasshensyn ikke kan diskuteres her. 
meutvalg som kan møte situasjoner preget av vonde livserfaringer. I likhet med skolesangbøkene kan det synes som om menighetene viker unna tema som berører vanskelige livserfaringer. Bare én av salmeplanene har med to salmer om dette tema, «Alt ble med ett så stille $\gg$ og «Noen må våke ». I møte med død, mobbing, foreldres samlivsbrudd m.m. må mange barn leve med sin angst og usikkerhet. I forbindelse med store nasjonale ulykker har det vært etterlyst kjente salmer som kan ivareta den berørtes liv i situasjoner der tryggheten vakler.

\section{Bibelsanger}

Bibelsanger er en salmekategori som ikke fantes i skolesangbøkene. ${ }^{16}$ I trosopplæringens salmeplaner har den imidlertid fått en relativt stor plass. Bibelsangene gjenforteller bibelhistorien i metrisk form, altså Bibelens fortellinger i verseform. Menighetenes salmeplaner ser ut til å legge større vekt på bibelsanger enn hva salmeboken gjør. Ni forskjellige bibelsanger er ført opp på listene. Menighetene har hentet disse fra Sanger for de små og Barnesalmeboka, ikke fra de offisielle salmebøkene. Bibelens fortellinger og fortellingstradisjon ivaretas av sanger som $\ll$ Har du hørt om Abraham», «I ørkensand », og «En mann gikk fra Jerusalem». Denne type salmer har lang tradisjon som bibelundervisning for barn i kirken. Bibelfortellingen har også en sentral plass i skolens arbeidsmåter for å formidle bibelsk lærestoff. I L 97 var fortellingen helt sentral i KRL-faget. «Både når det gjelder Bibelen, kristendommens historie og de andre religioner og livssyn, er det lagt stor vekt på presentasjon gjennom fortelling» (L 97, 1996, s. 91). Videre understrekes at $\ll[b]$ ruk av salmer og sanger skal følge arbeidet med faget på alle trinn» (s. 91). A «synge inn» lærestoff har vært et innarbeidet pedagogisk grep også i skolen, jf. også Luthers bruk av salmer.

Totalinntrykket av trosopplæringens salmeplaner er at de viser et bredere sammensatt salmeutvalg enn hva skolesangbøkene gjør. De skal dekke hele det kristne liv og læregrunnlag, mens salmerepertoaret i skolesangbøkene tar utgangspunkt i den folkekirkelige kulturelle situasjon, ikke i kirkens trosdimensjon.

\section{SAMKLANG MELLOM KIRKE OG SKOLE?}

Skolesangen har vært viktig for å styrke salmenes stilling i folket (Rong \& Holter, 2014, s. 90). I Nordhymn-undersøkelsen svarte 86 $\%$ av de norske informantene at de i hovedsak hadde lært de salmene som de kunne, i skolen. Bare $9 \%$ sa at kirke og menighetsarbeid hadde vært den viktigste impulsen for deres salmekunnskap (Straarup, 2001, s. 22).

I antologien om skolesangbøkene undersøkte jeg hvordan salmeutvalget plasserer seg mellom kultur og tro. Skolesangbøkenes salmerepertoar er i hovedsak knyttet til første trosartikkel, folkets livserfaringer og de kristne høytidene. Det kirkelige trosperspektivet er ikke skolens anliggende. I 1969 vedtok Stortinget at kristendomsundervisningen ikke lenger skulle være kirkens dåpsopplæring. Det var foreldrenes og kirkens eget ansvar å oppdra barna til kristen tro. Skolefagets oppgave var å støtte foreldrene i deres oppdrageransvar (Lied, 2008, s. 57). Salmenes funksjon i skolen har først og fremst vært å bidra til danning av kristen kulturell identitet gjennom formidling av tradisjoner som støtter opp om nasjonal og folkelig identitet. Et av karakteristikaene ved skolesangbøkenes salmetekster er at de er

16 Skolesangbøkene har derimot en del spirituals, noe som ikke forekommer i menighetenes trosopplæringsplaner. 
kulturåpne, og de formidler tema som «egner seg for barn» (Rong \& Holter, 2014, s. 89f). Salmeutvalget i de lokale trosopplæringsplanene viser samme tendens, dog med et sterkere innslag av salmer til bruk i gudstjenesten.

Trosopplæringsplanens forord sier at Dnk ønsker å spille på lag med skole og barnehage. «Menighetens lokale plan for trosopplæring må ses i sammenheng med skolens plan for religionsundervisning og barnehagens rammeplan» (Dnk, 2010, s. 3). I tillegg til «kirkens tro og tradisjon» og «kristen tro i praksis» har trosopplæringsplanen «livstolkning og livsmestring» som bærende elementer (Dnk, 2010, s. 15). Når Kunnskapsløftet (LK06) i fagplanen for RLE på sin side sier at «livstolkning» er en viktig funksjon ved faget, kan dette tyde på delvis sammenfallende interesser. $\ll$ Kunnskaper om religioner og livssyn og om den funksjon disse har både som tradisjon og aktuelle kilder til tro, moral og livstolkning, står sentralt i faget $\gg($ LK06, 2013, s. 45).

Samtidig er det tydelige forskjeller i kirkens og skolens målsettinger. I forbindelse med overgangen til KRL ble det presisert at skolens religionsfag ikke skulle være «en arena for forkynnelse. Faget skal gi kunnskap om, ikke opplæring til, en bestemt tro» (L 97, 1996, s. 89). Hensikten med faget var å fremme åpenhet, og «bidra til innsikt, respekt og dialog på tvers av tros- og livssynsgrenser og fremme forståelse og toleranse i religiøse og moralske spørsmål» (L 97, 1996, s. 89).

Det nye faget ble problematisk for en foreldregruppe tilhørende Human-Etisk Forbund. De klaget faget inn for Den europeiske menneskerettighetsdomstolen (EMD) i Strasbourg. I 2007 fikk kla- gerne medhold. EMD fant at prinsippet om objektiv, nøytral, pluralistisk og kritisk tenkning ikke var godt nok ivaretatt. Det var heller ikke fritaksretten fra religiøse aktiviteter (Lied, 2008, s. 63). «Religiøse aktiviteter» defineres ut fra Opplæringslovens $\$$ 2-4 som «deltakelse i resitering av bønner fra ulike religioner, salmesang, utanatlæring (sic!) av religiøse tekster og deltakelse i dramatiseringer med religiøst innhold. » (Inst $\mathrm{O} \mathrm{nr}$. 95 [1996-97]; Veiledning L97 KRL) (Lied, 2008, s. 61). ${ }^{17}$

Som en konsekvens av dommen ble alle formuleringer om å støtte opp om den enkelte elevs personlige identitet, fjernet. Delvis fritak fra faget ble beholdt, men foreldre trenger ikke lenger søke om det. Om deltaking i religiøse aktiviteter sier dommen at begrepet «deltaking» kan erstattes med observering av slike aktiviteter. Gjennom observasjon får elevene med seg læreinnholdet i disse aktivitetene (Lied, 2008, s. 63). Dette innebærer at salmetekster skal læres av alle elever, men elever kan bli fritatt fra å synge dem fordi dette kan defineres som religiøs praksis. Kjennskap til salmens innhold skal foregå gjennom analytiske undervisningsformer. Dermed har salmesang i skolen, og spesielt i RLE-undervisningen, kommet i klemme.

I fagplanen for RLE finnes altså ikke begrepet «identitet», heller ikke formuleringer som støtter opp om personlig tro. I læreplanens generelle del brukes begrepet fortsatt, men hensikten er å oppnå nasjonal identitet fremmet gjennom kunnskapsformidling. Opplæringen «må fremme demokrati, nasjonal identitet og internasjonal bevissthet. Den skal utvikle samhørighet med andre folk og menneskenes felles livsmiljø, ...» (LK06, 2013 , s. 4). Samtidig er utvikling av person-

17 Sidsel Lieds artikkel «KRL-faget i Strasbourg. Presentasjon av dom og dissens i EMD og skisse av en mulig vei videre» gir utfyllende dokumentasjon. 
lig identitet tatt med $\mathrm{i}$ «Læringsplakaten» av 2010 som et av prinsippene for opplæring, men uten at religiøs opplæring nevnes eksplisitt. Skolen skal «stimulere elevene i deres personlige utvikling og identitet, i det å utvikle etisk, sosial og kulturell kompetanse og evne til demokratiforståelse og demokratisk deltakelse» (LK06, 2013, s. 25). Identitet er et mangetydig begrep som knyttes til ulike arenaer og funksjoner, noe jeg ikke kan gå videre inn på her. Men slik jeg ser det, bidrar både kulturell identitet og religiøs identitet til livstolkning.

I kirkens trosopplæringsplan er identitetsskaping et gjennomgående mål. Tro og praksis går hånd i hånd. Enheten av tro og dåp skal være en ressurs for utviklingen av egen identitet (Dnk, 2010, s. 5). «Trosopplæringen har som et sentralt anliggende å styrke barn og unges identitet og gi hjelp til livsmestring» (Dnk, 2010, s. 18). Dette uttrykker et klart religiøst identitetsmål som skolen ikke har. Trosopplæringsplanen deler imidlertid skolens mål om felles kulturell identitet. Kapitlet «Vi deler kristne tradisjoner og verdier» sier at kirkens trosopplæring gjennom markering av høytider, kirkeår og livsriter kan

«bidra til å bygge religiøs identitet og kulturell tilhørighet hos barn og unge. [...] Gjennom å dele kristne tradisjoner og verdier bidrar trosopplaringen til å bygge identitet og holdninger som vil komme både individet og felleskapet til gode» (Dnk, 2010, s. 9f).

En slik presisering åpner etter min mening for at kirken fortsatt kan være en ressurs for skolen, til tross for at målene for identitet er forskjellige.

Hva så med salmenes påvirkningskraft? Er salmesang uttrykk for trosutøvelse, eller er salmer først og fremst uttrykk for kulturelt, nasjonalt felleseie? Ovenfor viste jeg til salmer som en felles kirkelig uttrykksform for tro og erfaringer. Det er liten tvil om at salmer har evne til å påvirke og å appellere til følelser. Trosidentitet vil alltid kunne oppstå i forlengelsen av en religiøs tekst. For kristendommen gjelder dette både salmetekster og bibeltekster. Hvordan den oppleves, avhenger dels av innhold, dels av konteksten den brukes i. Konteksten salmen synges i innvirker også på opplevelse. Et klasserom gir andre tolkningsrammer enn kirkehuset som med hele sin symbolikk legger til rette for utøvelse av tro. Det er forskjell på forkynnelse som form og forkynnelse som innhold. Religiøse tekster som appliseres på leseren/sangeren, er i seg selv bærer av et religiøst budskap. Tolking av budskapet kan skje i møte mellom tekst og leser uten å gå veien om f.eks. en lærers utlegging eller forklaring. Skolen legger ikke til rette for forkynnelse, men innholdet i salmetekstene forutsetter at tro er mulig. Hva en tekst rører ved i et menneskes (barns) liv, kan ingen kontrollere (Rong \& Holter, 2014, s. 88f). Salmetekster brukt i skolen er spesielt «sårbare» i så måte.

Derfor er det relevant å spørre om noen salmetekster er mer egnet i skolen enn andre. Er f.eks. salmer som beskriver og omtaler Gud, mer egnet enn salmer som direkte henvender seg til Gud eller Jesus i bønnens og lovsangens form? Om det første er tilfelle, vil skolen stå igjen med et svært begrenset salmeutvalg. For det første fordi adressaten i mange salmer endrer karakter underveis og veksler mellom beskrivelse og lovprisning, f.eks. «No livnar det i lundar». Fra å beskrive Guds natur skifter den i siste vers til direkte lovprisning av Gud: «[D]å me med vigsla tunge, / med kjærleik heil og klår, / alt utan brest og sprunge / skal lova Herren vår!» (N 13, 2013, s. nr. 844). For det andre vil et slikt repertoar utelukke mange av de tradisjonelle 
og mest brukte salmene, f.eks. «Her kommer dine arme små > som gjennomgående er en tilbedelsessalme: «Vi løper deg med sang imot / og kysser støvet for din fot, / å salig stund, å søte natt / da du ble født, vår sjeleskatt!»(N 13, 2013, s. nr. 36). Fullstendig nøytralitet er ikke mulig. Så vel personer som tekster bærer med seg sine verdier i møte med mennesker. Livstolkning handler om mer enn religiøst ståsted, det handler også om å se seg selv i forhold til sine omgivelser, sin kultur og sin historie. Visse tekster er så sterkt forankret i kulturen at å kjenne dem er nødvendig for livstolkning. Jeg mener at salmer er en slik type tekster.

Salmer hører til i skolen av kulturelle årsaker. De ivaretar tradisjon som er viktig for livstolkning. De som av religiøse årsaker ikke kan synge med, har støtte for fritak i lovverket. Men om dette medfører at lærerne sløyfer salmesang fordi det er en enkel løsning på problemet, er dette diskutabelt ut fra hensynet til kulturell arv. Mange foreldre ønsker fortsatt at barna skal lære salmer i skolen, ikke minst julesalmer, bl.a. for å videreføre tradisjon.

\section{TA SANGEN TILBAKE!}

Hvordan står det så til med kirken? Synger den? Ja, det har kirken alltid gjort. Synger barna? De mange aktivitetene knyttet til kirkens trosopplæring vitner om at salmesang fortsatt lever i beste velgående. Menighetenes lokale salmeplaner har et variert salmerepertoar som avspeiler kirkens tro og egenart. De støtter opp om både kristen og kulturell identitet. Gud gir - vi deler er et grunnlagsdokument i Dnk for opplæring i og til tro. Den forutsetter salmesang. Men prinsipielle overveielser om bruk av sang og musikk er imidlertid lite fremtredende, noe som kunne forventes i en luthersk folkekirke der salmesang står sentralt.
Hva så med skolen? Kan salmer synges i skolen? Både skole og kirke ønsker å legge til rette for barns livstolkning. Å synge salmer har lang tradisjon i skolen. Skolen har bl.a. gjennom salmer formidlet en felles kulturell arv som er viktig å videreføre. Her kan skole og kirke gå hånd $\mathrm{i}$ hånd fordi skolesangbøkenes og trosopplæringens salmerepertoar i stor grad har felles kulturell arv. Konteksten har betydning for hvilke føringer som legges på sangen. I kirkens rom er forkynnelse legitimt og ønskelig. Klasserommet er undervisningens sted som også skal ta hensyn til barn fra mange religioner og livssyn.

Forskning har vist at fellessang i det norske folk over tid har vært synkende. Det er mer populært å bli sunget for av profesjonelle artister enn å synge selv. For å ta sangen tilbake som felles allsang må både kirke og skole fortsette å synge til tross for at hensikten med sangen ikke er identisk. I denne oppgaven kan skole og kirke gjensidig støtte og hjelpe hverandre.

\section{LITTERATUR}

Beckmann, Hege Bjørnestøl \& Breistein, Ingunn Folkestad. (2007). "Tor du synge den sangen fortsatt?" Bruk av sang og musikk i KRLfag og skolehverdag - en forskningsrapport. Hentet fra http://ansgarhogskole.no/file/ forskningsrapport-krlnett-februar-2007.pdf Bjørnstad, Fred Ola, Olsen, Eiliv \& Rong, Marit. (2014). Med sang! Perspektiver på norske skolesangbøker etter 1814. Oslo: Novus Forlag.

Den norske kirke. (1985). Norsk Salmebok. Oslo: Verbum.

Den norske kirke. (1997). Salmer 1997: tillegg til Norsk Salmebok. Oslo: Verbum.

Den norske kirke. (2010). Plan for trosopplaring. Gud gir - vi deler. Oslo.

Den norske kirke. (2011). Gudstjeneste for Den 
norske kirke. Stavanger: Eide Forlag.

Den norske kirke. (2013). Norsk salmebok 2013. For kirke og hjem. For kyrkje og heim. Stavanger: Eide Forlag AS.

Det kongelige kirke-, utdannings- og forskningsdepartement. (1996). Læreplanverket for den 10-årige grunnskolen. Oslo: Nasjonalt læremiddelsenter.

Hansson, Karl-Johan, Bohlin, Folke \& Straarup, Jørgen. (2001). Dejlig er jorden Psalmens roll i nutida nordiskt kultur- och samhällsliv. Åbo: Åbo Akademis Förlag.

Harbsmeier, Eberhard. (2008). Salmebog og katekismus. I S.-Å. Selander, \& K.-J. Hansson (Red.), Martin Luthers psalmer $i$ de nordiska folkens liv (s. 262-273). Lund: Arcus förlag.

Hjelde, Sigurd, Lønning, Inge \& Rasmussen, Tarald. (1982). Martin Luther. Verker i utvalg (Bind V). Oslo: Gyldendal Norsk Forlag.

Holter, Stig Wernø. (2008). Kom tilbe med fryd. Innføring i liturgikk og hymnologi (2. utg.). Oslo: Solum Forlag.

Holter, Stig Wernø. (2011). Nytt norsk salmeleksikon (Bind 1). Trondheim: Tapir forlag.

Landstad, M.B. (1973). M.B. Landstads kirkesalmebok. Revidert og forøket av stiftsprost Gustav Jensen med bistand av en komité. Skoleutgave med melodier. Oslo: Andaktsbokselskapets forlag.

Lied, Sidsel. (2008). KRL-faget i Strasbourg. Presentasjon av dom og dissens i EMD og skisse av en mulig vei videre. Norsk Teologisk Tidsskrift, 1, 55-71. Hentet fra https://itportalen.hib.no/ntt/2008/01/,DanaInfo=www. idunn.no+krl-faget_i_strasbourg_-_presentasjon_av_dom_og_dissens_i_emd_ ogskisseavenm

Norges offentlige utredninger. (1981). Norsk Salmebok. Forslag til felles salmebok for Den norske kirke, NOU 1981:40. Oslo - Bergen -
Tromsø: Universitetsforlaget.

Olsen, Eiliv. (2009). Hva er egentlig grunnleggende ferdigheter i musikkfaget? I $\mathrm{H}$. Traavik, O. Hallås, \& A. Ørvig (Red.), Grunnleggende ferdigheter $i$ alle fag (s. 228241). Oslo: Universitetsforlaget.

Pedlex. Norsk skoleinformasjon. (2013). Kunnskapsløftet. Mål og innhold i grunnskolen. Viby: Scanprint AS.

Pétursson, Pétur. (2001). Psalmer, böner och religiös socialisation. I K.-J. Hansson, F. Bohlin, \& J. Straarup (Red.), Dejlig er jorden. Psalmens roll $i$ nutida nordiskt kultur- och samhällsliv (s. 59-88). Åbo: Åbo Akademis förlag.

Rong, Marit. (2009). Det liturgiske møte. Språk og gudsmetaforer i Den norske kirkes høymesse. Bergen: Universitetet i Bergen.

Rong, Marit \& Holter, Stig Wernø. (2014). Mellom kultur og tro. Salmene i skolesangbøkene. I F. O. Bjørnstad, E. Olsen, \& M. Rong (Red.), Med Sang! Perspektiver på norske skolesangbøker etter 1814 (s. 64-92). Oslo: Novus Forlag.

Rypdal, Marit. (1973). Sanger for de små. Oslo: IKO's Læremidler.

Røshol, Jan. (2007). Bruk av salmer i KRL-faget: Undersøkelse ved 3 skoler $i$ en bydel $i$ Bergen. Bergen: Norsk Lærerakademi.

Selander, Sven-Åke. (2009). Ny kunskap om Luthers psalmer i de nordiska folkens liv? I S.-Å. Selander, \& K.-J. Hansson (Red.), Martin Luthers psalmer i de nordiska folkens liv (s. 705-708). Lund: Arcus förlag.

Selander, Sven-Åke \& Hansson, Karl-Johan. (2008a). Introduktion. I S.-Å. Selander, \& K.-J. Hansson (Red.), Martin Luthers psalmer i de nordiska folkens liv (s. 13-19). Lund: Arcus Förlag.

Selander, Sven-Åke \& Hansson, Karl-Johan. (2008b). Martin Luthers psalmer $i$ de nordiska folkens liv. Lund: Arcus Förlag. 
Straarup, Jørgen. (2001). Kollektivt musicerande som väg till psalmerna. I K.-J. Hansson, F. Bohlin, \& J. Straarup (Red.), Dejlig er jorden. Psalmens roll i nutida nordiskt kultur-och samhällsliv (s. 38-58). Åbo: Åbo Akademis förlag.

Sundkvist, Bernice. (2008). Er hilft uns frei aus aller Not - Teologi och kommunikation i Luthers psalmer. I S.-Å. Selander, \& K.-J. Hansson (Red.), Martin Luthers psalmer $i$ de nordiska folkens liv (s. 19-28). Lund: Arcus Förlag.

Thomissøn, Hans. (1569). Den danske Psalmebog / met mange Christelige Psalmer / Ordentlig tilsammenset / formeret oc forbedret. Kiøbenhaffn.
Tveit, Sigvald. (2001). De høyest verdsatte salmene i Norge. I K.-J. Hansson, F. Bohlin, \& J. Straarup (Red.), Dejlig er jorden. Psalmens roll $i$ nutida nordiskt kultur- och samhällsliv (s. 260-275). Åbo: Åbo Akademis förlag. Verbum \& IKO-Forlaget AS. (1999). Barnesalmeboka. Oslo: Verbum/IKOForlaget.

Walgermo, Alf Kjetil. (2015, 24.04). Ta songen tilbake i skulen, Kommentar. Vårt Land.

Winsnes, Ole Gunnar. (2001). Salmene i menneskenes hjerter. I K.-J. Hansson, F. Bohlin, \& J. Straarup (Red.), Dejlig er jorden. Psalmens roll $i$ nutida nordiskt kultur-och samhällsliv (s. 136-171). Åbo: Åbo Akademis förlag.
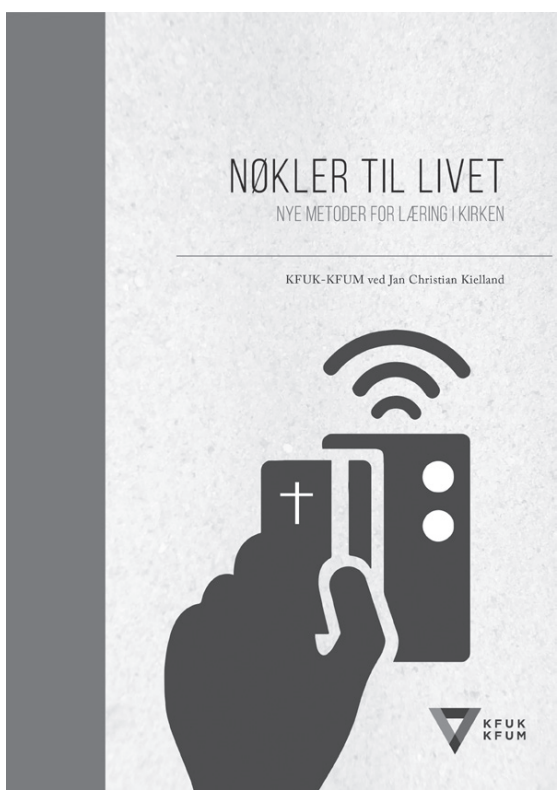

* IFOLGE KIFO Og KUNS KONFIRMANTUNDERSØKELSER I 2007/2008 OG 2012/2013. $\rightarrow$ Knytter kristen tro til det konfirmanter helst vil lære om*: vennskap og meningen med livet.

$\rightarrow$ Opplegg for over 50 timer kunnskaping med ungdom.

$\rightarrow$ Omsetter forskning på læring i kirken til konkrete metoder.

\section{Pris: 299 kr}

KJØP BOKA HOS VIVO
eller på
BUTIKK.KFUK-KFUM.NO

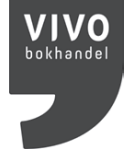

